\title{
Can the rapid semiquantitative estimation of serum $C$ reactive protein be adapted for the management of bacterial infection?
}

\author{
NP RICHARDS, ${ }^{*}$ TS ELLIOTT, $\dagger$ RJ POWELL, ${ }^{*}$ C O’CALLAGHAN, $\ddagger$ P FRANKLIN $\ddagger$ \\ From the Departments of *Immunology, †Microbiology, and $\ddagger$ Child Health, University Hospital, Queen’s \\ Medical Centre, Nottingham
}

SUMMARY Serum $\mathrm{C}$ reactive protein concentrations measured by a laboratory based assay were compared with the semiquantitative results obtained with a visual agglutination method (Wellcotest, CRP kit). Using this agglutination kit, diluting serum $1 / 10$ and $1 / 20$ gave $C$ reactive protein results which could be of more clinical value than those obtained using the $1 / 2,1 / 4,1 / 8$, and 1/16 dilutions recommended by the manufacturers. The kit was also used on the ward by junior medical staff, who showed that after minimal training reproducible serum $\mathrm{C}$ reactive protein results could be obtained.

Measurement of $\mathrm{C}$ reactive protein (CRP) concentration is useful in diagnosing and monitoring bacterial infections. ${ }^{1-6}$ Serial measurements of serum CRP values have shown that they rise considerably within the first $24 \mathrm{~h}$ of an illness and a concentration of CRP of $100 \mathrm{mg} / \mathrm{l}$ or more has been suggested as being indicative of significant bacterial infection. In particular, patients with acute leukaemia or other malignancies, including those who are neutropenic, ${ }^{78}$ rarely have $\mathrm{CRP}$ values greater than 50 $\mathrm{mg} / \mathrm{l}$ as a result of the disease process alone, and therefore in these patients CRP estimation may also be of value in the early diagnosis of bacterial infection.

The clinical decision to start antibiotic treatment is often made without the benefit of the CRP result because rapid estimations are not readily available. We have therefore investigated the use of a rapid, yet inexpensive, semiquantitative CRP test which could be performed on the ward by medical personnel. The results were compared with those obtained using a laboratory based immunoassay.

\section{Material and methods}

CRP concentrations were determined in serum samples obtained from 150 patients using a laboratory based latex enhanced immunoassay ${ }^{y}$ and also semiquantitatively by the CRP Wellcotest rapid latex test kit (Wellcome Diagnostics, Dartford, England). In this kit polystyrene latex particles coated with antibodies to human CRP are used to detect the presence of CRP in serum by agglutination.

Initially, 28 samples were diluted $1 / 2,1 / 4,1 / 8$, and $1 / 16$ in normal saline for semiquantitative esti-

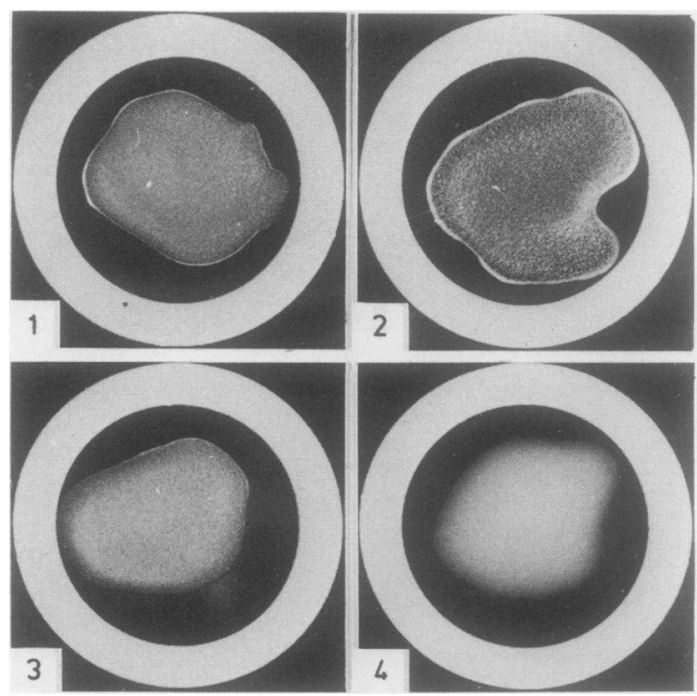

Fig. 1 Agglutination reactions at 2 min using the Wellcotest CRP kits. 1 is a weak positive, 2 a strong positive, 3 the kit control positive, and 4 the kit control negative. 


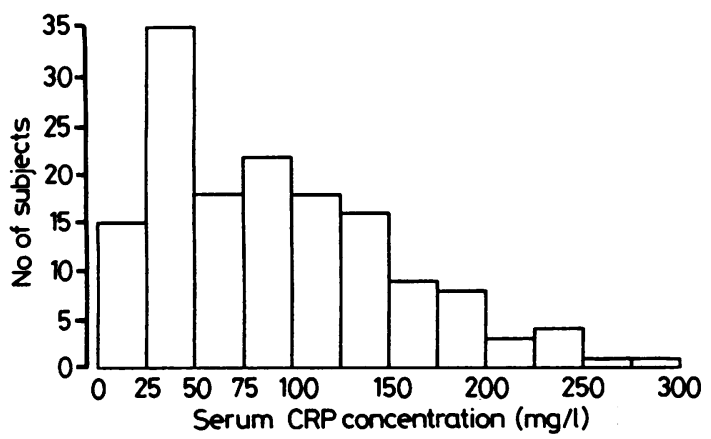

Fig. 2 Distribution of $C$ reactive protein concentrations in serum samples obtained from 150 patients determined by latex enhanced immunoassay.

mation, as recommended by the manufacturers. Fifty microlitres of the diluted serum was then added to one drop of CRP latex from the Wellcotest kit and these were mixed on a glass slide. After 2 min the presence of any agglutination was recorded and was interpreted as a positive result (Fig. 1). This procedure was repeated using $1 / 10$ and $1 / 20$ dilutions of the serum samples. A further 122 serum samples were tested at $1 / 10$ and $1 / 20$ dilutions only. A serum sample with a high CRP value of $484 \mathrm{mg} / 1$ was tested at dilutions of $1 / 2,1 / 10$, and $1 / 20$ to assess the effect of antigen excess.

Ten resident doctors from the Department of
Paediatrics in Nottingham performed Wellcotest kit assays on five different serum samples. After only basic instruction concerning the use of a bench centrifuge and variable pipette (5-200 $\mu$ l, Gilson), they tested the serum samples at dilutions of $1 / 10$ and $1 / 20$ without prior knowledge of the laboratory result. Control positive and negative serum samples are supplied with the kit for reference.

\section{Results}

Fig. 2 shows the distribution of the serum CRP concentrations of the 150 samples determined by the laboratory immunoassay, with an overall range of 1 to $295 \mathrm{mg} / \mathrm{l}$.

In Fig. 3 the CRP kit results are recorded as either positive or negative agglutination and the range of results obtained using the manufacturer's recommended serum dilutions of $1 / 2,1 / 4,1 / 8$, and $1 / 16$ are shown in Fig. 3 compared with the CRP value in $\mathrm{mg} / \mathrm{l}$. At a $1 / 2$ dilution all 28 sera gave positive agglutination whereas at a $1 / 16$ dilution only 23 gave positive agglutination. Further dilutions were then made to try to obtain positive or negative agglutinations around the $100 \mathrm{mg} / \mathrm{l}$ value. Fig. 3 shows the results using $1 / 10$ and $1 / 20$ serum dilutions, compared with serum CRP values in $\mathrm{mg} / \mathrm{l}$. At a dilution of $1 / 10$ all the CRP values gave a positive reaction whereas at $1 / 20$ only those samples with CRP concentrations $>100 \mathrm{mg} / \mathrm{l}$ were positive.
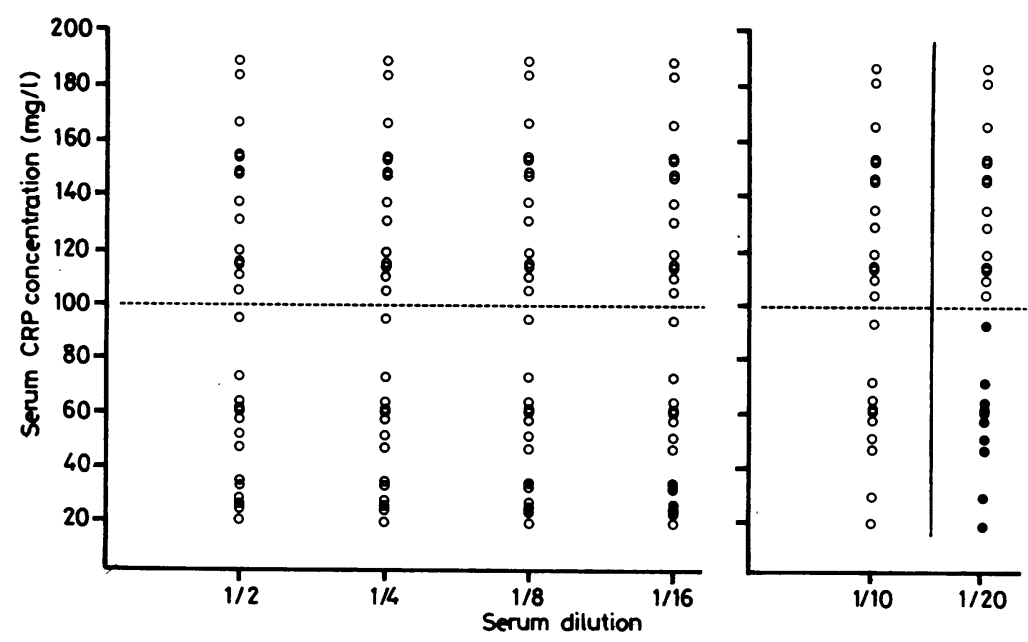

Fig. 3 CRP results for 28 sera determined by a latex enhanced immunoassay and at various dilutions using the Wellcotest kit. Positive agglutination is denoted by open circles and negative agglutination by closed circles. (a) dilutions recommended by the manufacturers $(1 / 2,1 / 4,1 / 8,1 / 16)$. (b) dilutions recommended by the authors $(1 / 10$, 1/20). 
Table 1 Comparison of serum $C$ reactive protein (CRP) values determined by latex enhanced immunoassay and the Wellcotest kit $^{*}$

\begin{tabular}{lllc}
\hline $\begin{array}{l}\text { Range of CRP } \\
\text { values }(m g / l)\end{array}$ & $\begin{array}{l}\text { No of } \\
\text { sera }\end{array}$ & \multicolumn{2}{l}{ No of positive kit agglutination results } \\
\cline { 2 - 4 } & & \multicolumn{2}{l}{ Serum dilution } \\
\cline { 2 - 3 } & & $1 / 10$ & $1 / 20$ \\
\hline $0-50$ & 50 & 1 & 0 \\
$51-99$ & 40 & 38 & 3 \\
$>100$ & 60 & 60 & 58 \\
\hline
\end{tabular}

*Tests were performed by laboratory staff.

Table 2 Results obtained by junior medical staff using the Wellcotest kit at 1/20 serum dilution

\begin{tabular}{lll}
\hline $\begin{array}{l}\text { No of } \\
\text { sera tested }\end{array}$ & $\begin{array}{l}\text { No of positive kit } \\
\text { agglutination results } \\
\text { at 1/20 dilution }\end{array}$ & $\begin{array}{l}\text { Range of CRP } \\
\text { values (mg/l) } \\
\text { (laboratory assay) }\end{array}$ \\
\hline 37 & 1 & $0-99$ \\
23 & 23 & $>100$ \\
\hline
\end{tabular}

$\mathrm{CRP}=\mathrm{C}$ reactive protein.

The results of the 150 serum CRP values determined by trained laboratory staff using both the latex enhanced immunoassay and the Wellcotest kit are given in Table 1 . Ninety samples had CRP concentrations $<100 \mathrm{mg} / \mathrm{l}$ by the standard laboratory assay; of these, 87 gave negative and three gave positive reactions using the Wellcotest kit at a serum dilution of $1 / 20$. The CRP values of the three samples which gave positive agglutination were 99, 99, and $61 \mathrm{mg} / \mathrm{l}$. Of the 60 serum samples with CRP values $>100 \mathrm{mg} / \mathrm{l}, 58$ gave positive agglutination and two gave negative results using the kit assay at $1 / 20$ serum dilutions. The CRP values of these two negative samples were 105 and $110 \mathrm{mg} / \mathrm{l}$.

The serum sample with a CRP value of $484 \mathrm{mg} / \mathrm{l}$ was negative at a dilution of $1 / 2$ but positive at both $1 / 10$ and $1 / 20$.

Sixty samples of serum were tested by medical staff using the kit method: 23 had CRP values greater than $100 \mathrm{mg} / \mathrm{l}$ and 37 had CRP values less than $100 \mathrm{mg} / \mathrm{l}$ (Table 2). All of the samples with CRP concentrations $>100 \mathrm{mg} / \mathrm{l}$ and only one sample with a CRP value of less than $100 \mathrm{mg} / \mathrm{l}$ gave positive agglutinations at a dilution of $1 / 20$. The kit test took between 7 and 8 min to perform and no difficulties were encountered when reading the agglutination reaction.

\section{Discussion}

The results confirm that the Wellcotest kit is simple and easy to perform. It can be carried out rapidly by junior medical staff after minimal training, requires only small samples of serum extracted from either capillary or venous blood," and needs only basic equipment.

Serum CRP concentrations $>100 \mathrm{mg} / \mathrm{l}$ have been suggested as being indicative of bacterial infection in the appropriate clinical situation. ${ }^{5}$ Using the kit with serum dilutions of $1 / 10,38$ of 40 sera with CRP values of 50 to $99 \mathrm{mg} / \mathrm{l}$ gave positive agglutination results, whereas at a $1 / 20$ serum dilution only three of the samples were positive. The combination of CRP agglutination results at a serum dilution of $1 / 10$ and $1 / 20$ therefore helps to select those sera with CRP values $>100 \mathrm{mg} / \mathrm{l}$. The manufacturers, however, recommend serum dilutions of $1 / 2,1 / 4,1 / 8$, and $1 / 16$. The CRP range which is encompassed by the $1 / 16$ dilution is $20-189 \mathrm{mg} / \mathrm{l}$ and therefore does not allow further differentiation within this range, particularly those in excess of $100 \mathrm{mg} / \mathrm{l}$ which might be indicative of bacterial infection. Our findings suggest that $1 / 10$ and $1 / 20$ serum dilutions are of more clinical value, giving a semiquantitative cut off of CRP around $100 \mathrm{mg} / \mathrm{l}$. According to the manufacturers, low serum dilutions-for example, 1/2-are subject to a prozone effect leading to false negative results. We did not encounter this problem with the 150 samples tested. But we did show this effect when using a serum sample with a particularly high CRP value of $484 \mathrm{mg} / \mathrm{l}$. No prozone effect was seen at $1 / 10$ serum dilution with any samples. There is no precise cut off at $100 \mathrm{mg} / \mathrm{l}$ using the kit with $1 / 10$ and $1 / 20$ serum dilutions, but only about $3 \%$ of samples would give false negative results at a $1 / 20$ serum dilution.

The three serum samples positive at $1 / 20$ serum dilution with CRP values $<100 \mathrm{mg} / \mathrm{l}$ were tested for rheumatoid factors by the conventional latex and sheep cell agglutination tests, because previous reports have suggested interference by rheumatoid factors in CRP agglutination tests. ${ }^{10}$ All three sera were negative.

The results suggest that the CRP values obtained with the kit are of sufficient accuracy to be of value in the early diagnosis and management of patients with significant bacterial infection. Various rapid assays for determining CRP values have recently been described," but these are laboratory based and require expensive equipment and laboratory trained personnel. Therefore, with the current discussion on the contribution that medical staff can make by performing simple pathology tests on the wards, ${ }^{12}$ particularly out of normal laboratory working hours, this rapid CRP test should be of interest. Similarly, small hospital laboratories may find this a useful method when CRP is requested by physicians managing patients with bacterial infections. 
We thank the Special Trustees for Nottingham University Hospitals for their research grant, the Wellcome Foundation Ltd for supplying the CRP Wellcotest Kits, Professor D Hull for allowing us to perform the survey, and Mrs S Brailsford and Miss E Allen for typing the manuscript.

\section{References}

' Sabel K-G, Hanson LA. The clinical usefulness of C-reactive protein (CRP) determination in bacterial meningitis and septicaemia in infancy. Acta Paediatr Scand 1974;63:381-8.

${ }^{2}$ Philip AGS, Hewitt JR. Early diagnosis of neonatal sepsis. Pediatrics 1980;65: 1036-41.

${ }^{3}$ Clarke D, Cost K. Use of serum C-reactive protein in differentiating septic from aseptic meningitis in children. $J$ Pediatr 1983;102:718-20.

4 Sabel K-G, Wadsworth CH. C-reactive protein (CRP) in early diagnosis of neonatal septicaemia. Acta Paediatr Scand 1979;68:825-31.

${ }^{5}$ Mackie PH, Crockson RA, Stuart J. C-reactive protein for rapid diagnosis of infection in leukaemia. J Clin Pathol 1979;32:1253-6.
- Peltola HO. C-reactive protein for rapid monitoring of infections of the central nervous system. Lancet 1982;ii:980-3.

' Hindocha P, Campbell CA, Gould JDM, Wojciechowski A, Wood CBS. Serial study of C-reactive protein in neonatal septicaemia. Arch Dis Child 1984;59:435-8.

${ }^{8}$ Rose PE, Johnson SA, Meakin M, Mackie PH, Stuart J. Serial study of C-reactive protein during infection in leukaemia. $J$ Clin Pathol 1981;34:263-6.

' O'Callaghan C, Franklin P, Elliott T, Deverill I, Richards N, Powell RJ. C reactive protein levels in neonates; determined by a latex enhanced immunoassay. J Clin Pathol 1984;37:1027-8.

${ }^{10}$ Deyo RA, Popee RM, Persellin RH. Interference by rheumatoid factor with detection of $\mathrm{C}$-reactive protein by the latex agglutination method. $J$ Rheumatol 1980; 7:279-87.

" Harris RI, Stone PCW, Hudson AG, Stuart J. C reactive protein rapid assay techniques for monitoring resolution of infection in immunosuppressed patients. J Clin Pathol 1984;37:821-5.

12 Bamber MG. Pathology tests in the side-room. Lancet 1984;ii: 755 .

Requests for reprints to: Dr RJ Powell, Consultant Immunologist, University Hospital, Queen's Medical Centre, Nottingham NG7 2UH, England. 